\title{
River-Corridor Habitat Dynamics, Lower Missouri River
}

Intensive management of the Missouri River for navigation, flood control, and power generation has resulted in substantial physical changes to the river corridor. Historically, the Missouri River was characterized by a shifting, multithread channel and abundant unvegetated sandbars. The shifting channel provided a wide variety of hydraulic environments and large areas of connected and unconnected off-channel water bodies.

Beginning in the early 1800 s and continuing to the present, the channel of the Lower Missouri River (downstream from Sioux City, Iowa) has been trained into a fast, deep, single-thread channel to stabilize banks and maintain commercial navigation. Wing dikes now concentrate the flow, and revetments and levees keep the channel in place and disconnect it from the flood plain. In addition, reservoir regulation of the Missouri River upstream of Yankton, South Dakota, has substantially changed the annual hydrograph, sediment loads, temperature regime, and nutrient budgets.

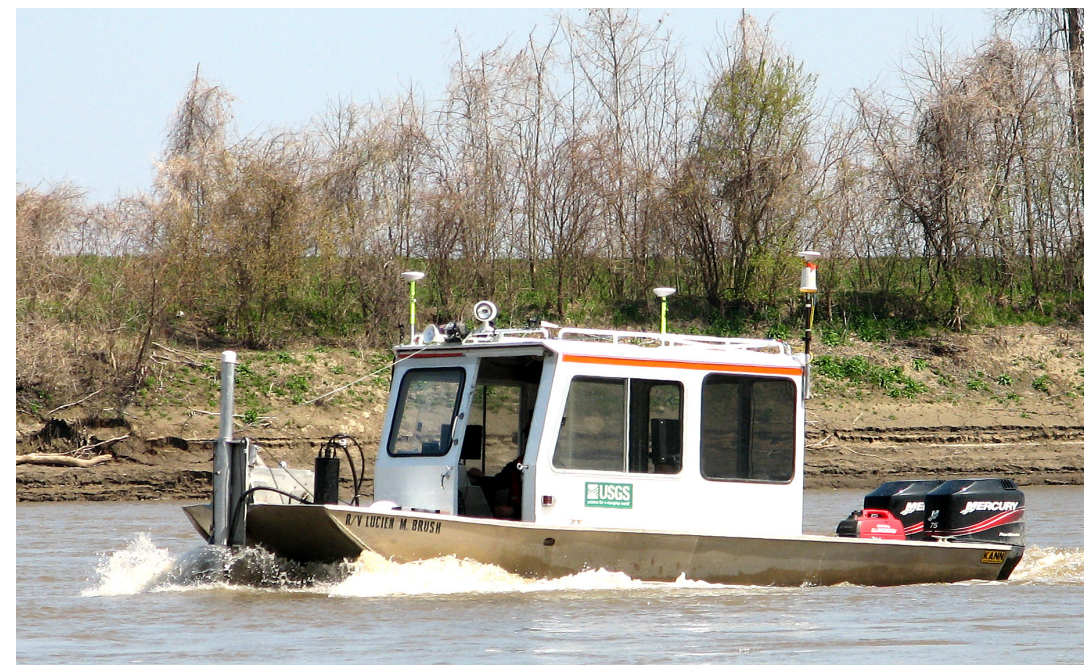

The U.S. Geological Survey's Missouri River habitat assessment research vessel, the Lucien M. Brush.

While changes to the Missouri River have resulted in broad social and economic benefits, they have also been associated with loss of river-corridor habitats and diminished populations of native fish and wildlife species. Today, Missouri River stakeholders are seeking ways to restore some natural ecosystem benefits of the Lower Missouri River without compromising traditional economic uses of the river and flood plain.

\section{Research Objectives}

The research objective of the River-Corridor Habitat Dynamics Project is to improve the scientific basis for ecological restoration of large rivers. Ecological restoration seeks to restore the physical, biological, and chemical processes of a formerly functional ecosystem. Efforts to restore the Missouri River have focused mostly on restoring some of the hydrologic and geomorphic characteristics of the former river, with the assumption that biotic and abiotic ecosystem processes will respond favorably.

Considerable uncertainty exists in the restoration process, including fundamental questions about the physical system. For example, how do hydrologic and geomorphic characteristics combine to create the right kinds of habitats at the right times and places? How does the physical template of habitats vary over time as the river erodes and deposits sediments?

This project is designed to improve understanding of the links between habitat availability in the river corridor and habitat use by significant biota, including endangered and invasive species. This information is essential for optimizing ecosystem benefits of reservoir release schedules, assessing cost/benefit ratios of restoration, and providing support for adaptive management of rehabilitation projects. 
Measuring and Modeling the River

The River-Corridor Habitat Dynamics Project emphasizes quantitative measurement of fundamental physical processes in the river at scales meaningful to habitat assessment. The deep, swift, and muddy Missouri River presents considerable challenges to making basic measurements of the river, including depth, velocity, substrate, and elevation characteristics. We use an integrated hydroacoustic mapping system that combines the precision positioning of real-time kinematic global positioning (RTK GPS), survey-grade echosounding, a bed-material classification system, and acoustic Doppler current profiling. Data from the acoustic acquisition system are used to create maps of the river, including those that can be used to assess habitat availability.

Because habitat varies with discharge, assessment of habitat availability has to account for discharge variation, either by focusing on a single index discharge or by evaluating habitat over a range of discharges. We use the hydroacoustic maps to construct, calibrate, and validate one- and two-dimensional hydraulic models. The hydraulic models allow us to evaluate habitat availability in the channel and on the flood plain as habitat area varies with discharge.

Establishing how fish, birds, and invertebrates use these habitats during their life cycles is critical. Quantifying habitat selection by fish is especially challenging because of difficulties in locating fish in the deep, turbid water of the Missouri River. We are working closely with fish ecologists to track fish that are tagged with acoustic and radiotelemetry devices. Telemetry provides point locations from which habitat patches can be identified, defined, mapped, and modeled. The mapped patches quantify characteristics of used habitats, unused habitats, and their spatial variability. Explicitly linking habitat availability to habitat use allows fish ecologists to evaluate which habitats the fish select under various conditions.

The River-Corridor Habitat Dynamics project is collaborating in a variety of interdisciplinary, multiagency studies to quantify habitats of pallid sturgeon (Scaphirhynchus albus), Asian carp (Cyprinus carpio carpio), flathead catfish (Pylodictis olivaris), and other species, and to combine this information with species' life-history information to provide a scientific foundation for restoration of the Lower Missouri River ecosystem.

\section{Project Bibliography}

Elliott, C.M., and Jacobson, R.B., 2006, Geomorphic classification and assessment of channel dynamics in the Missouri National Recreational River, South Dakota and Nebraska: U.S. Geological Survey Scientific Investigations Report 2006-5313, 66 p., http://pubs. er.usgs.gov/usgspubs/sir/sir20065313.

Elliott, C.M., Reuter, J.M., and Jacobson, R.B., 2009, Channel morphodynamics in four reaches of the Lower Missouri River, 2006-07: U.S. Geological Survey Scientific Investigations Report 2009-5074, 258 p., http://pubs.usgs.gov/sir/2009/5074/.

Jacobson, R.B., and Galat, D.L., 2006, Flow and form in rehabilitation of large-river ecosystems-An example from the Lower Missouri River: Geomorphology, v. 77, no. 3-4, p. 249-269.

Jacobson, R.B., ed., 2006, Science to support adaptive habitat management, Overton Bottoms North Unit, Big Muddy Fish and Wildlife Refuge, Missouri: U.S. Geological Survey Scientific Investigations Report 2006-5086, 116 p.,

http://pubs.usgs.gov/sir/2006/5086/.

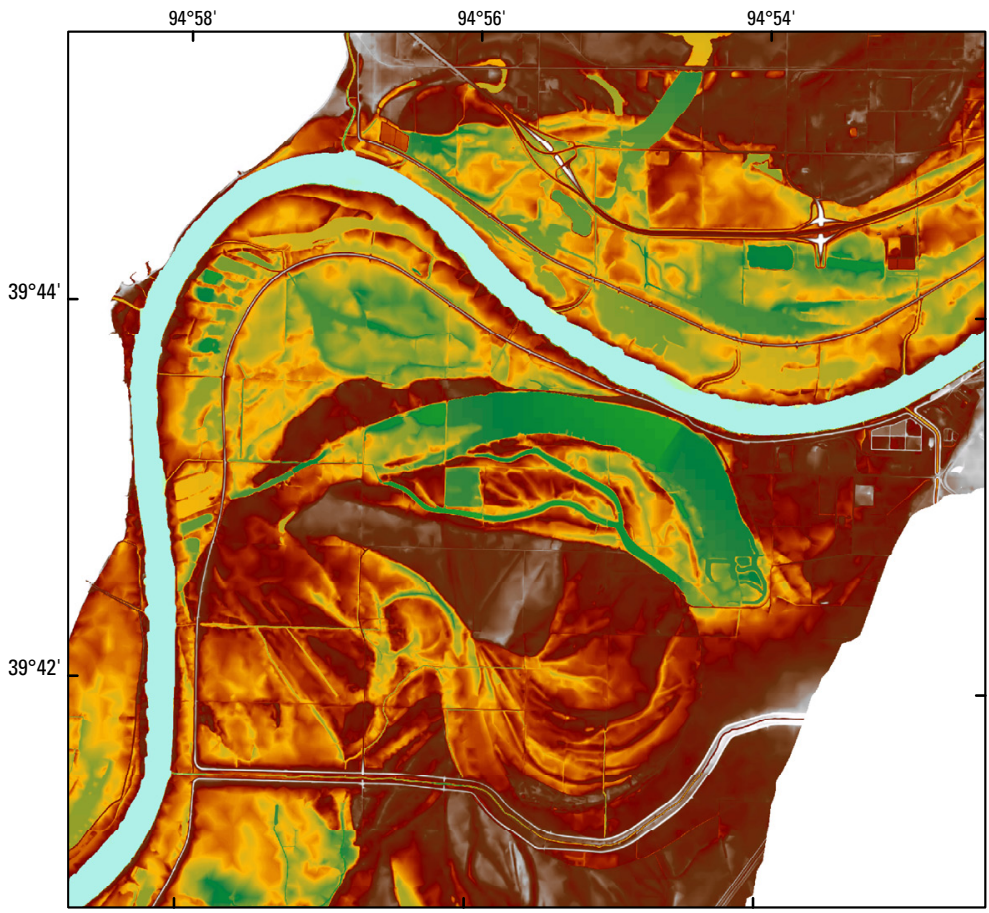

Mapping of floodplain habitats by using the high-resolution topographic data and the Land Capability Potential Index (Jacobson and others, 2007).

Jacobson, R.B., and Galat, D.L., 2008, Design of a naturalized flow regime on the Lower Missouri River: Ecohydrology, v. 1 , no. 2 , p. $81-104$.

Jacobson, R.B., 2008, Analysis of pulsed flow modification alternatives, Lower Missouri River, 2005: U.S. Geological Survey OpenFile Report 2008-1113, 14 p., http://pubs.usgs.gov/of/2008/1113.

Jacobson, R.B., Blevins, D.W., and Bitner, C.J., 2009, Sediment regime constraints on river restoration-An example from the Lower Missouri River, in James, L.A., Rathburn, S.L., and Whittecar, G.R., eds., Management and restoration of fluvial systems with broad historical changes and human impacts: Denver, Colo., Geological Society of America Special Paper 451, p. 1-22.

Jacobson, R.B., Johnson, H.E., III, and Dietsch, B.J., 2009, Hydrodynamic simulations of physical aquatic habitat availability for pallid sturgeon in the Lower Missouri River, at Yankton, South Dakota, Kenslers Bend, Nebraska, Little Sioux, Iowa, and Miami, Missouri, 2006-07: U.S. Geological Survey Scientific Investigations Report 2009-5058, 67 p., http://pubs.usgs.gov/sir/2009/5058/.

Reuter, J.M., Jacobson, R.B., Elliott, C.M., and DeLonay, A.J., 2009, Assessment of Lower Missouri River physical aquatic habitat and its use by adult sturgeon (Genus Scaphirhynchus) 2005-07: U.S. Geological Survey Scientific Investigations Report 2009-5121, 81 p., http://pubs.er.usgs.gov/usgspubs/sir/sir20095121.

Reuter, J.M., Jacobson, R.B., Elliott, C.M., Johnson, H.E., III, and DeLonay, A.J., 2008, Hydraulic and substrate maps of reaches used by sturgeon (Genus Scaphirhynchus) in the Lower Missouri River, 2005-07: U.S. Geological Survey Data Series Report 386, 442 p., http://pubs.usgs.gov/ds/386/.

For more information concerning this publication, contact: Director, USGS Columbia Environmental Research Center 4200 New Haven Road, Columbia, M0 65201 (575) 875-5399 Or visit the Columbia Environmental Research Center Web site at: http://www.cerc.usgs.gov/ 